\title{
Long-term data for endemic frog genera reveal potential conservation crisis in the Bale Mountains, Ethiopia
}

\author{
David J. Gower, Roman K. Aberra, Silvia Schingler, Malcolm J. Largen \\ Ben Collen, Stephen Spawls, Michele Menegon, Breda M. Zimkus \\ Rafael de Sá, Abebe A. Mengistu, Finirte Gebresenbet, Robin D. Modre \\ SAMY A. SABER and SIMON P. LOADER
}

\begin{abstract}
Populations of many frogs have declined alarmingly in recent years, placing nearly one third of the $>6,000$ species under threat of extinction. Declines have been attributed largely to habitat loss, environmental degradation and/or infectious diseases such as chytridiomycosis. Many frogs undergo dramatic natural population fluctuations such that long-term data are required to determine population trends without undue influence of stochastic factors. We present long-term quantitative data (individuals encountered per person hour of searching) for four monotypic frog genera endemic to an Afromontane region of exceptional importance but growing conservation concern: one endemic to the Ethiopian highlands (Spinophrynoides osgoodi) and three endemic to the Bale Mountains (Altiphrynoides malcolmi, Balebreviceps hillmani, Ericabatrachus baleensis), collected during 15 field trips to the Bale Mountains between 1971 and 2009. Only a single confirmed sighting of $S$. osgoodi has been made since
\end{abstract}

DAVID J. GowER (Corresponding author) Department of Zoology, The Natura History Museum, London SW7 5BD, UK. E-mail d.gower@nhm.ac.uk

Roman K. Aberra Ethiopian Wildlife Conservation Authority, Addis Ababa, Ethiopia

Silvia Schwaller, Abebe A. Mengistu* and Simon P. Loader University of Basel, Institute of Biogeography, Department of Environmental Sciences, Basel, Switzerland

Malcolm J. Largen Formby, UK

BEN COLLEN Institute of Zoology, Zoological Society of London, London, UK

STEPHEN SPAWLS Spixworth, Norwich, UK

Michele Menegon Sezione di Zoologia dei Vertebrati, Museo Tridentino di Scienze Naturali, Trento, Italy

BREDA M. ZimKUs Museum of Comparative Zoology, Harvard University, Cambridge, Massachusetts, USA

RAFAEL DE SÁ Department of Biology, University of Richmond, Richmond, Virginia, USA

Fikirte Gebresenbet and Samy A. Saber $\dagger$ Department of Biology, Addis Ababa University, Addis Ababa, Ethiopia

RoBIN D. Moore Conservation International, Arlington, Virginia, USA

*Also at: Department of Biology, Addis Ababa University, Addis Ababa, Ethiopia

$\dagger$ Also at: Zoology Department, Faculty of Science, Al-Azhar University, Assiut, Egypt

Received 1 April 2011. Revision requested 16 May 2011

Accepted 26 July 2011.
1995. The other three species have also declined, at least locally. E. baleensis appears to have been extirpated at its type locality and at the same site $B$. hillmani has declined. These declines are in association with substantial habitat degradation caused by a growing human population. Chytrid fungus has been found on several frog species in Bale, although no dead or moribund frogs have been encountered. These results expose an urgent need for more amphibian surveys in the Bale Mountains. Additionally, we argue that detrimental human exploitation must be halted immediately in at least some parts of the Harenna Forest if a conservation crisis is to be averted.

Keywords Africa, Afromontane, amphibians, Bale Mountains National Park, chytrid, decline, Ethiopia, management

This paper contains supplementary material that can be found online at http://journals.cambridge.org

\section{Introduction}

Dopulations of many frogs have declined alarmingly in 1 recent years, placing nearly one third of the $>6,000$ species under threat of extinction (IUCN, 2010). Declines have been attributed largely to habitat loss, environmental degradation and/or infectious diseases such as chytridiomycosis (Stuart et al., 2008; Kilpatrick et al., 2010). Many frogs undergo dramatic natural population fluctuations (e.g. Pechmann et al., 1991; Semlitsch et al., 1996) such that longterm data are required to determine population trends without undue influence of stochastic factors (e.g. Meyer et al., 1998; Marsh, 2001; Green, 2003). Long-term quantitative data are generally lacking for the vast majority of frog species, particularly in the tropics (Adeba et al., 2010; Largen \& Spawls, 2010). For Africa this is exacerbated by a general relative scarcity of attention to conservation biology research despite many threats to its globally important biota (Pimm, 2007). Here we present long-term quantitative data for four frog genera endemic to an Afromontane region of exceptional importance but growing conservation concern. 


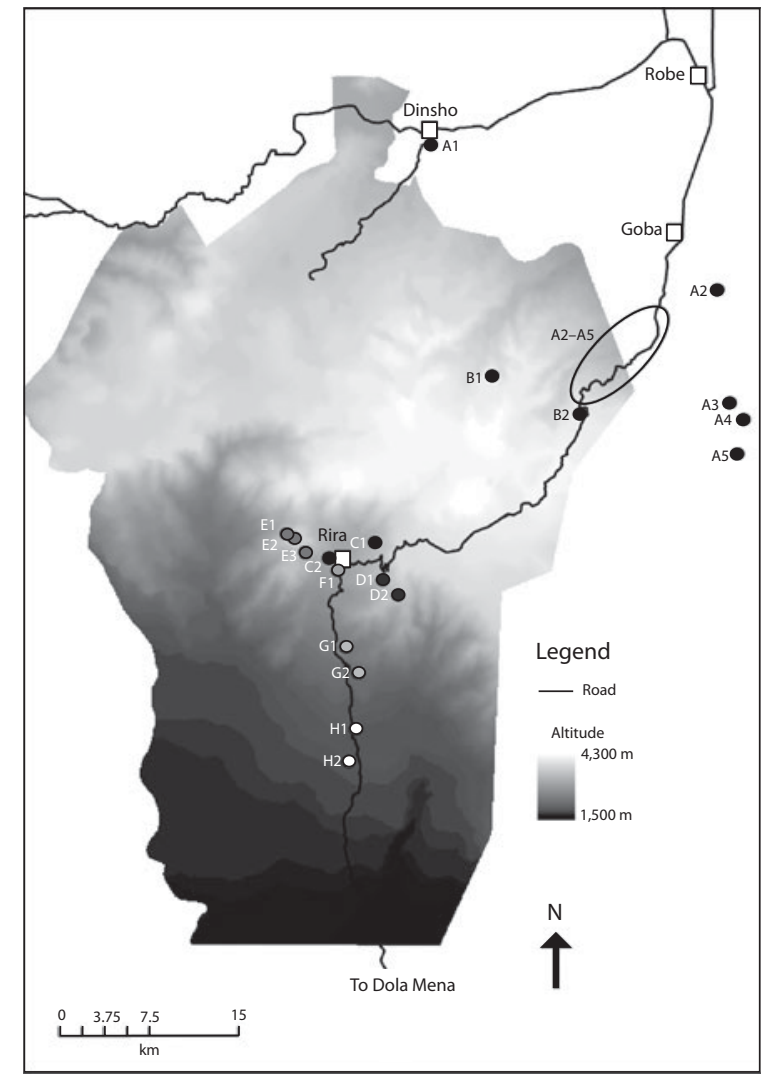

FIG. 1 Map of the Bale Mountains National Park, Ethiopia showing Park boundary, local villages and towns (squares), and sampling localities A-H (dots) referred to in the text and Table 1. The dots labelled $\mathrm{A}_{2}$ to $\mathrm{A}_{5}$ are based on coordinates given in error by Grandison (1978) and Largen (2001); these localities are actually close to the Goba-Rira road, approximately within the area marked by the ellipse labelled A2-A5. Rira, in the centre of the Park, is at $6.771^{\circ} \mathrm{N}, 39.725^{\circ} \mathrm{E}$.

The Bale Mountains lie in southern Ethiopia, east of the Rift Valley (Fig. 1). The Mountains are a high (up to nearly $4,400 \mathrm{~m}$ ) and extensive massif with rich biodiversity, including many unique, rare, spectacular and threatened taxa. Hillman (1986: 255) considered the Mountains 'a centre of faunal endemicity, probably with the highest rate of animal endemicity for a terrestrial habitat anywhere in the world'. The region incorporates the largest single area $\left(>4,000 \mathrm{~km}^{2}\right)$ in Africa over 3,000 $\mathrm{m}$ altitude, and is a crucially important reservoir of globally threatened Afromontane and Afroalpine habitats (Largen \& Spawls, 2010).

The highest part of the region, the Sanetti Plateau and associated peaks, comprises Afroalpine grasslands with a highly endemic biota. To the south, the Sanetti Plateau terminates at the Harenna escarpment that drops from 3,200 to $2,000 \mathrm{~m}$ in $8 \mathrm{~km}$. This escarpment exhibits a dramatic vegetation zonation from the plateau grasslands through low heather scrub, giant heather (Erica spp.) forest, Hagenia, bamboo and Podocarpus forest, high altitude woodland and into medium altitude rainforest (Friis, 1986; Miehe \& Miehe, 1993, 1994). This is one of the largest natural areas of forest remaining in Ethiopia. Towards the west, north and east the Sanetti Plateau falls away more gently and change in vegetation is less abrupt, with Afroalpine grasslands giving way to heather moorlands and, below c. 3,000 m, Hagenia forest.

A substantial area (c. 2,200 $\mathrm{km}^{2}$ ) of the region is covered by the Bale Mountains National Park, established in 1971 but not yet formally gazetted by the Ethiopian government. The Park is the most important conservation area in Ethiopia (Frankfurt Zoological Society, 2007), one of the most important in Africa (Largen \& Spawls, 2010), and one of 34 Conservation International global biodiversity hotspots. The Park is a BirdLife International Important Bird Area, and on the Tentative List to qualify as a World Heritage Site. Many people live and exploit natural resources within the Park, and their activities are the primary threat to the native biodiversity (Frankfurt Zoological Society, 2007). Conservation efforts are currently focused on habitats, and on flagship threatened bird and mammal species, which are concomitantly the taxa that are best known scientifically. For example, the Park is the focus of the Ethiopian Wolf (Canis simensis) Conservation Programme (e.g. SilleroZubiri et al., 1997; Atickem et al., 2009), and the main remaining stronghold of the mountain nyala Tragelaphus buxtoni (Malcolm \& Evangelista, 2005) and Bale monkey Chlorocebus djamdjamensis (Mekonnen, 2008; Mekonnen et al., 2010). The Park is important as a water source for c. 12 million people and of outstanding social, scenic and cultural value (Hillman, 1988; Frankfurt Zoological Society, 2007). A management plan for the Park was published recently (Frankfurt Zoological Society, 2007).

About 15 amphibian species (all anurans) have been reported from the Bale Mountains, including 10 endemics (Largen, 2001; Largen \& Spawls, 2010). The Bale Mountains National Park is an Alliance for Zero Extinction site, partly because of its endemic amphibians (Alliance for Zero Extinction, 2010). Given the Park's importance for their conservation we focus here on four monotypic frog genera: all endemic to Ethiopia and three endemic to the Bale Mountains.

\section{Previous work up to 1986}

Although there is a long history of human habitation in the area, the Bale Mountains remained largely unexplored scientifically until the middle of the 2oth century. The Chicago Field Museum's W.H. Osgood collected some amphibians and reptiles in 1926-1927. Partly in association with other British colleagues, M.J. Largen carried out extensive collections between 1971 and 1975. Early expeditions were centred around Dinsho/Dinshu and the northern slopes below the Sanetti Plateau. In 1983 it become feasible to reach 

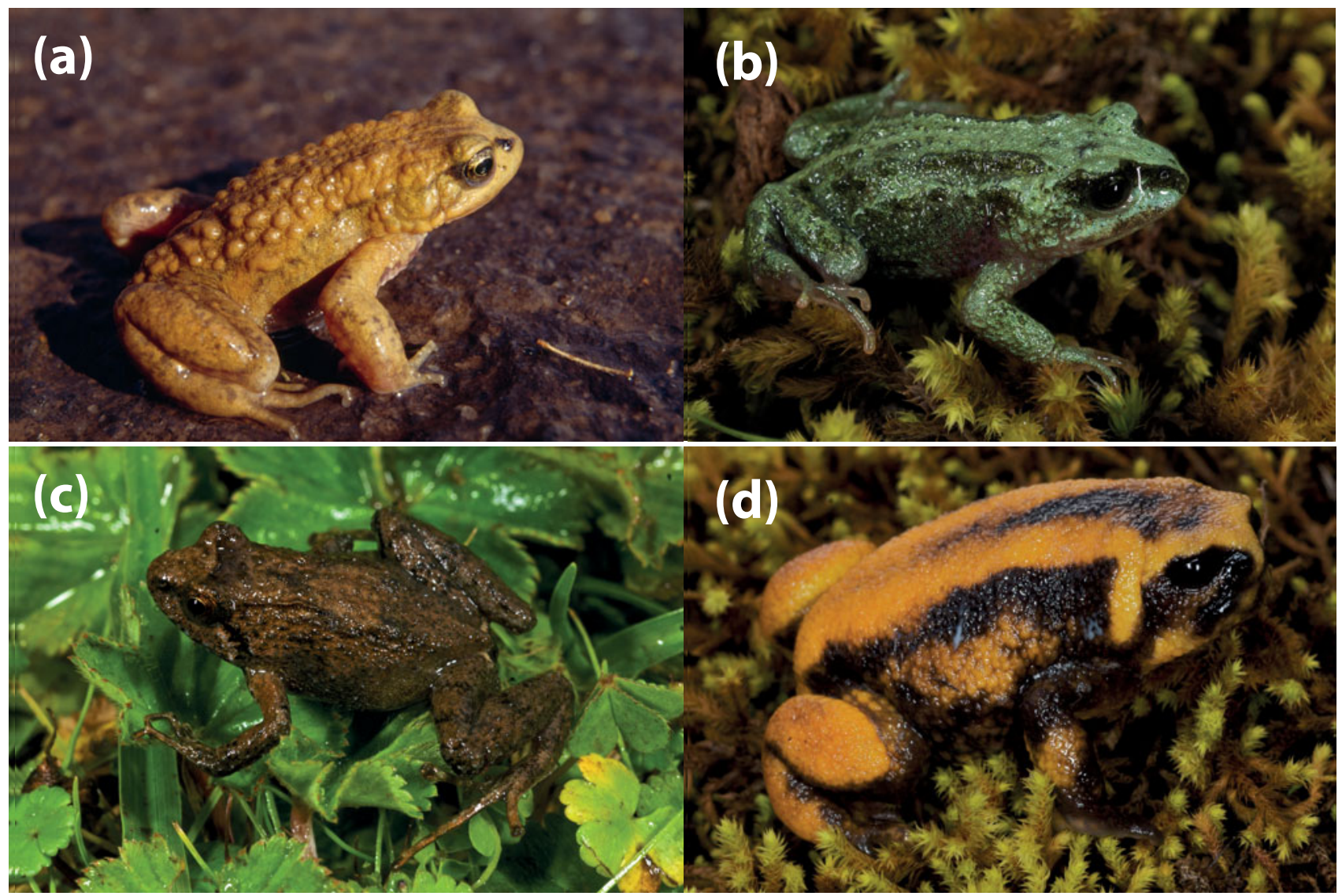

Plate 1 The four endemic Ethiopian monotypic frog genera studied: (a) Spinophrynoides osgoodi, (b) Altiphrynoides malcolmi,

(c) Ericabatrachus baleensis, and (d) Balebreviceps hillmani. S. osgoodi is endemic to the highlands of Ethiopia; the others are endemic to the Bale Mountains. (a) by S. Spawls, (b-d) by M. Menegon.

the Harenna Forest on the southern side of the massif by road. Conscious of the conservation threat posed by the new road the Ethiopian Wildlife Conservation Organization arranged an expedition with Addis Ababa University to conduct a preliminary survey of the Harenna Forest in August 1986.

We follow the taxonomy of the latest comprehensive treatment of Ethiopian amphibians (Largen, 2001; Largen \& Spawls, 2010). The localities reported for Spinophrynoides, Altiphrynoides and some other Bale Mountain frogs as south-east of Goba (Grandison, 1978; Largen, 2001) are in error. These localities are south of Goba along the GobaRira road; the reported altitudes are approximately correct but the coordinates are not.

\section{Focal species}

Fuller accounts of the systematics, natural history and conservation biology of the four species are given in Appendix 1.

Spinophrynoides osgoodi (Plate 1a) was described in 1932 from specimens collected between 1926 and 1927, from an imprecise type locality ('Gedeb Mountains', Loveridge, 1932). It has been recorded in Ethiopia from beyond the Bale
Mountains but the vast majority of records are from north and south of the Sanetti Plateau, typically in montane forest but extending also into open moorland at 1,950-3,520 m (Largen, 2001). It is a small to medium (snout-vent length to $62 \mathrm{~mm}$ ) species that lays strings of eggs in small pools that develop into tadpoles before metamorphosing into froglets (Grandison, 1978; Largen, 2001). The presence of this Ethiopian endemic genus in the Bale Mountains has been overlooked by some non-herpetologists and conservation managers (e.g. WCMC, 1993; Miehe \& Miehe, 1994) because S. osgoodi was not classified in the genus Spinophrynoides until 1987. It has been categorized as Vulnerable on the IUCN Red List since the first Global Amphibian Assessment in 2004 (Stuart et al., 2008; IUCN, 2010).

Altiphrynoides malcolmi (Plate 1b) was described in 1978 from $>160$ specimens collected between 1971 and 1975 from the northern side of the Sanetti Plateau. The species was collected subsequently from the Harenna escarpment. It is endemic to the Bale Mountains, reported from altitudes of 3,200-4,000 $\mathrm{m}$, spanning the upper limits of the Schefflera-Hagenia-Hypericum forest to Afroalpine moorland (Largen, 2001). This small species (snout-vent length $<32 \mathrm{~mm}$, Largen, 2001) has internal fertilization and lays 
small clutches of large eggs communally in moist terrestrial sites that hatch into non-feeding tadpoles that remain on land (Grandison, 1978). Because A. malcolmi has been classified in Altiphrynoides only since 1987 the presence of this endemic genus has been overlooked in some summaries of the fauna (e.g. WCMC, 1993; Miehe \& Miehe, 1994). It has been categorized as Endangered on the IUCN Red List since the first Global Amphibian Assessment in 2004 (Stuart et al., 2008; IUCN, 2010).

Ericabatrachus baleensis (Plate 1c) is endemic to the Harenna escarpment and was described in 1991 from specimens collected in 1986. Twenty-two of the types were collected from the margins of a stream in giant Erica forest at the type locality (Tulla Negesso) for Balebreviceps hillmani (see below) at 3,200 $\mathrm{m}$, with one specimen coming from a stream at Katcha, at 2,400 m. We know of no published records beyond the type series. The reproduction and life history of E. baleensis are unknown but it has been postulated to lay terrestrial eggs that possibly develop directly without a tadpole stage (Largen, 1991). The presence of $E$. baleensis and its endemicity have been overlooked by at least some important works on the Bale Mountains (e.g. Miehe \& Miehe, 1994). It has been categorized as Endangered on the IUCN Red List since the first Global Amphibian Assessment in 2004 (Stuart et al., 2008; IUCN, 2010).

B. hillmani (Plate 1d) was described in 1989 from specimens collected in 1986 from a single locality (Tulla Negesso). To the best of our knowledge no subsequent collections had been made, nor any reports published for any other locality (e.g. Largen \& Spawls, 2010). The types were collected from beneath logs and boulders within giant Erica forest $50 \mathrm{~m}$ below the timber line on the Harenna escarpment (Largen \& Drewes, 1989). The presence of B. hillmani and its endemicity were overlooked by at least some important works on the Bale Mountains (e.g. Miehe \& Miehe, 1994). The breeding biology and life history of B. hillmani are unknown but it is predicted to have terrestrial eggs with direct development (Largen \& Drewes, 1989; Müller et al., 2007). It has been categorized as Endangered on the IUCN Red List since the first Global Amphibian Assessment in 2004 (Stuart et al., 2008; IUCN, 2010).

\section{Methods}

We evaluated data on the change in abundance of the four endemic genera, combining information from five previous field visits (1971-1986) with that from seven teams that conducted amphibian and reptile survey fieldwork on 10 subsequent occasions (1994-2009). All six expeditions that took place this century included the four focal species as specific targets, and the teams were equipped with detailed historical locality information for these taxa. Fieldwork took place by day and night, employing visual and audio encounter surveys. Searching included netting of streams and ponds, inspecting trees and shrubs, digging leaf litter and surface soil, rolling logs and rocks, raking leaf litter, and searching through ground vegetation by hand, including some intensive searches in $25 \mathrm{~m}^{2}$ quadrats. Particular effort was applied along the edge of water bodies. Details of the field effort undertaken and frogs encountered are provided in Appendix 2. All teams recorded numbers of individuals of the four endemic frog genera. Teams 11-14 recorded search effort (as number of person hours searching) while in the field. Search effort data for the other teams, including expeditions between 1971 and 1999, were compiled retrospectively from the field notebooks of expedition members. Frogs other than the four focal species were noted but precise numbers of individuals encountered were generally not recorded.

Field data were converted into numbers of frogs encountered per person hour of searching. These data were grouped into eight localities (Fig. 1): (A) North of Sanetti (2,800-3,900 m), mostly around Dinsho and south of Goba up to the northern edge of the Sanetti Plateau, (B) Sanetti Plateau (c. 3,800-4,150 m), (C) Tulla Negesso and areas close to the road, down to the lower edge of the main centre of Rira village (2,900-3,250 m), (D) Fute and Kotinsa, superficially less disturbed (than Tulla Negesso) giant Erica forest along the Harenna escarpment east of the road $(3,200-3,255 \mathrm{~m})$, (E) Degebato and Galema, superficially less disturbed giant Erica forest along the Harenna escarpment west of the road (3,200-3,300 m), (F) In the vicinity of the WWF hut below Rira, down to the lower rim of the Rira basin $(2,700-2,850 \mathrm{~m})$ but close to the road, $(G)$ in and immediately around the Katcha clearing (c. 2,350-2,450 m), and $(\mathrm{H})$ around the Shawe River bridge and areas close to the road south of here, including the marshy clearing at Magano (c. 1,700$1,950 \mathrm{~m})$.

Likelihood of site-level extinction of frogs was assessed with optimal linear estimation (Cooke, 1980; Solow, 2005), a non-parametric method that allows extinction date to be estimated based on the distribution of most recent sightings. We applied the technique reported by Solow (2005) to generate an estimate of extinction date, with $95 \%$ confidence limits (see Appendix 3 for full details). Change in numbers of individuals over time was assessed by fitting models in a generalized additive modelling (GAM) framework. We used GAM to model sightings as a function of effort trend as a smooth, non-linear function of time, and to provide a framework for testing the statistical significance of changes. GAM is advantageous in long-term trend analyses because it allows change in mean abundance to follow any smooth curve, not only linear forms (Fewster et al., 2000). Calculations were carried out using the $M G C V$ package (Wood, 2006) in $R$ v. 2.11 (R Development Core Team, 2010). 
TABLE 1 Numbers (and individuals per hour in parentheses) of the four species of frogs surveyed in the Bale Mountains across eight localities (A-H; see Methods for further details and Fig. 1) during 15 numbered field trips between 1971 and 2009.

\begin{tabular}{|c|c|c|c|c|c|c|c|}
\hline Month & Year & Trip & $\begin{array}{l}\text { Spinophrynoides } \\
\text { osgoodi }\end{array}$ & $\begin{array}{l}\text { Altiphrynoides } \\
\text { malcolmi }\end{array}$ & $\begin{array}{l}\text { Ericabatrachus } \\
\text { baleensis }\end{array}$ & $\begin{array}{l}\text { Balebreviceps } \\
\text { hillmani }\end{array}$ & $\begin{array}{l}\text { Total } \\
\text { hours }\end{array}$ \\
\hline \multicolumn{8}{|c|}{ (A) North of Sanetti } \\
\hline Dec. & 1971 & 1 & $2(0.13)$ & $2(0.13)$ & & & 16 \\
\hline Apr. & 1972 & 2 & & $3(1)$ & & & 3 \\
\hline Apr. & 1974 & 3 & $49(9.8)$ & $115(23)$ & & & 5 \\
\hline Apr. & 1974 & 4 & $32(1.6)$ & $75(3.75)$ & & & 20 \\
\hline Dec./Jan. & $1994 / 1995$ & 6 & & & & & 6 \\
\hline Sep. & 1996 & 7 & & $3(0.38)$ & & & 8 \\
\hline Dec. & 1996 & 8 & & & & & 6 \\
\hline Oct. & 1997 & 9 & & & & & 8 \\
\hline July & 2006 & 10 & & & & & 3 \\
\hline Sep. & 2006 & 11 & & $1(0.05)$ & & & 21.5 \\
\hline July/Aug. & 2008 & 12 & & & & & 4 \\
\hline \multicolumn{8}{|c|}{ (B) Sanetti Plateau } \\
\hline Dec. & 1971 & 1 & $3(0.5)$ & & & & 6 \\
\hline Dec./Jan. & $1994 / 1995$ & 6 & & & & & 6 \\
\hline Dec. & 1996 & 8 & & & & & 6 \\
\hline Oct. & 1997 & 9 & & & & & 8 \\
\hline July & 2006 & 10 & & & & & 3 \\
\hline Sep. & 2006 & 11 & & & & & 1.5 \\
\hline July/Aug. & 2008 & 12 & & & & & 9 \\
\hline June & 2009 & 14 & & & & & 15 \\
\hline \multicolumn{8}{|c|}{ (C) Tulla Negesso \& environs } \\
\hline Aug. & 1986 & 5 & $10(0.33)$ & $30(1)$ & $23(0.77)$ & $18(0.6)$ & 30 \\
\hline Dec./Jan. & $1994 / 1995$ & 6 & $?$ & & & $1(0.5)$ & 2 \\
\hline Sep. & 1996 & 7 & & $20+(1+)$ & & $1(0.05)$ & 20 \\
\hline Dec. & 1996 & 8 & & $18(3)$ & & $1(0.17)$ & 6 \\
\hline Oct. & 1997 & 9 & & & & & 8 \\
\hline July & 2006 & 10 & & & & & 15 \\
\hline Sep. & 2006 & 11 & & $3(0.1)$ & & $4(0.13)$ & 30.5 \\
\hline July/Aug. & 2008 & 12 & & $1(0.04)$ & & $4(0.17)$ & 23 \\
\hline Feb./Mar. & 2009 & 13 & & $3(0.26)$ & & $2(0.17)$ & 11.5 \\
\hline June & 2009 & 14 & & $1(0.1)$ & & $1(0.1)$ & 10.5 \\
\hline Sep. & 2009 & 15 & & $1(0.07)$ & & & 14 \\
\hline \multicolumn{8}{|c|}{ (D) Fute \& Kotinsa } \\
\hline July/Aug. & 2008 & 12 & & $4(0.1)$ & $1(0.03)$ & $3(0.08)$ & 39 \\
\hline Feb./Mar. & 2009 & 13 & & $5(0.48)$ & & $1(0.1)$ & 10.5 \\
\hline June & 2009 & 14 & & $5(0.2)$ & $2(0.08)$ & $14(0.56)$ & 25 \\
\hline Sep. & 2009 & 15 & & $1(0.14)$ & & & 7 \\
\hline \multicolumn{8}{|c|}{ (E) Degebato \& Galema } \\
\hline Sep. & 2006 & 11 & & & & & 5 \\
\hline July/Aug. & 2008 & 12 & & & & & 11 \\
\hline Feb./Mar. & 2009 & 13 & & & & $2(0.22)$ & 9 \\
\hline \multicolumn{8}{|c|}{ (F) Vicinity of WWF hut below Rira } \\
\hline Dec./Jan. & $1994 / 1995$ & 6 & & $40(10)$ & & & 4 \\
\hline July & 2006 & 10 & & & & & 4 \\
\hline July/Aug. & 2008 & 12 & & & & & 15 \\
\hline Feb./Mar. & 2009 & 13 & & & & & 8.5 \\
\hline June & 2009 & 14 & & & & & 5 \\
\hline \multicolumn{8}{|c|}{ (G) Katcha clearing } \\
\hline Aug. & 1986 & 5 & $25(1.32)$ & & $1(0.05)$ & & 19 \\
\hline July & 2006 & 10 & & & & & 9 \\
\hline Sep. & 2006 & 11 & & & & & 9 \\
\hline July/Aug. & 2008 & 12 & & & & & 8 \\
\hline Feb./Mar. & 2009 & 13 & & & & & 5 \\
\hline June & 2009 & 14 & & & & & 8 \\
\hline Sep. & 2009 & 15 & & & & & 6 \\
\hline
\end{tabular}


Table 1 (Continued)

\begin{tabular}{|c|c|c|c|c|c|c|c|}
\hline Month & Year & Trip & $\begin{array}{l}\text { Spinophrynoides } \\
\text { osgoodi }\end{array}$ & $\begin{array}{l}\text { Altiphrynoides } \\
\text { malcolmi }\end{array}$ & $\begin{array}{l}\text { Ericabatrachus } \\
\text { baleensis }\end{array}$ & $\begin{array}{l}\text { Balebreviceps } \\
\text { hillmani }\end{array}$ & $\begin{array}{l}\text { Total } \\
\text { hours }\end{array}$ \\
\hline \multicolumn{8}{|c|}{ (H) Shawe River bridge \& Magano } \\
\hline Aug. & 1986 & 5 & $1(0.06)$ & & & & 16 \\
\hline July & 2006 & 10 & & & & & 4 \\
\hline Sep. & 2006 & 11 & & & & & 3 \\
\hline June & 2009 & 14 & & & & & 19 \\
\hline Sep. & 2009 & 15 & & & & & 3 \\
\hline \multicolumn{8}{|c|}{ Tulla Negesso only* } \\
\hline Aug. & 1986 & 5 & $10(0.33)$ & $30(1)$ & $23(0.77)$ & $18(0.6)$ & 30 \\
\hline Dec./Jan. & $1994 / 1995$ & 6 & & & & $1(0.5)$ & 2 \\
\hline Sep. & 1996 & 7 & & & & $1(0.25)$ & 4 \\
\hline Dec. & 1996 & 8 & & & & $1(0.5)$ & 2 \\
\hline July & 2006 & 10 & & & & & 4 \\
\hline Sep. & 2006 & 11 & & & & $1(0.06)$ & 16.5 \\
\hline July/Aug. & 2008 & 12 & & $1(0.08)$ & & & 13 \\
\hline Feb./Mar. & 2009 & 13 & & $3(0.67)$ & & $1(0.22)$ & 4.5 \\
\hline June & 2009 & 14 & & & & $1(0.18)$ & 5.5 \\
\hline Sep. & 2009 & 15 & & $1(0.17)$ & & & 6 \\
\hline
\end{tabular}

*Also part of locality (C) and is the type locality of E. baleensis and B. hillmani.

\section{Results}

Raw encounter data are reported in Appendix 2 and summarized in Table 1. A single S. osgoodi (identified from a photograph provided by M. Hoffman) was found at Katcha on 14 October 2003 but we were aware of this visit and find only after our study had been completed and so it is not included in our quantitative analyses. S. Spawls possibly found three $S$. osgoodi in a clearing $3 \mathrm{~km}$ south of Rira (January 1995) but their identity has not been confirmed (possibly Altiphrynoides instead). No specimens were found by later expeditions during substantial fieldwork, so that to the best of our knowledge $S$. osgoodi has not been collected since 1986, perhaps observed only twice since then, and not observed since 2003 despite concerted attempts to locate specimens. From the quantitative data, Cooke's estimator gives an estimated date of extirpation of $S$. osgoodi from the sampled region of 2016 but the confidence interval, $\mathrm{CI}$, is wide (95\% CI 1999-2781; 80\% CI 2003-2100). The encounter rate data are too non-linear to use simple regression to test for significant decline but a GAM using sightings pooled across study sites showed a good fit, illustrating significant decline since the mid 1970s $(t=2.95, \mathrm{P}>0.05$; Fig. 2a).

More than 100 A. malcolmi were recorded in four visits during 1994-1999, most on the Harenna escarpment but also on the north-east edge of the Sanetti Plateau. A further 25 were found in six subsequent visits (2006-2009), all but one on the Harenna escarpment. Together these specimens extend the altitudinal range of the species to c. 2,5004,000 m (from 3,200-4,000 m, Largen, 2001). The Harenna specimens were found during the day, almost all under logs, and some (including all from the north-east edge of Sanetti) under rocks. Analysis of encounter data with GAM showed a significant decline in abundance using sightings pooled across study sites $(t=3.25, \mathrm{P}<0.05$; Fig. $2 \mathrm{~b})$.

Only three E. baleensis were found by the 10 expeditions post-1986 (1994-2009), and all of these in relatively undisturbed habitat east of the type locality. Despite dedicated searches no specimens have been found at the type locality or at Katcha since their original discovery. Statistical analysis is not appropriate for the patchy quantitative data but E. baleensis is probably extirpated or rare at the type locality. Comparison of the stream at the type locality at the time of discovery (1986) and the recent expeditions (20062009) reveals substantial habitat alteration (Plate 2). The stream is no longer a swift mountain torrent (Largen, 1991) but is now a broad, boggy, muddy and relatively slowflowing waterway heavily trampled by domesticated cattle. The stream is also now used by local people to wash clothes, with one section diverted to form a leat that serves the nearby dwelling. This habitat change happened between 1999 and 2006.

Six specimens of $B$. hillmani have been found at the type locality since the original collection in 1986. Only three of these were found in the six visits since 2006, despite considerable effort. Comparison of the type locality giant Erica forest in 1986 and 2006-2009 demonstrates substantial change (Plate 2). There is now a greatly reduced leaf litter, fewer trees, an almost compete absence of logs (removed for firewood and fencing), a human settlement on the edge of the forest, and an introduction of cows and other livestock that has resulted in the forest floor being heavily grazed, trampled and crossed by muddy tracks. At least two of the recent $B$. hillmani from the type locality were found under 
(a)

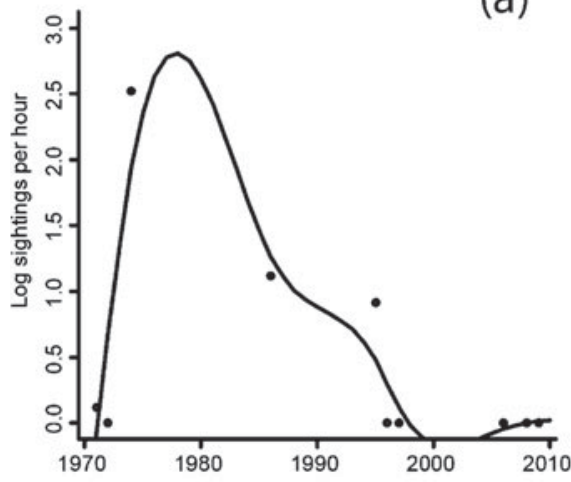

(c)

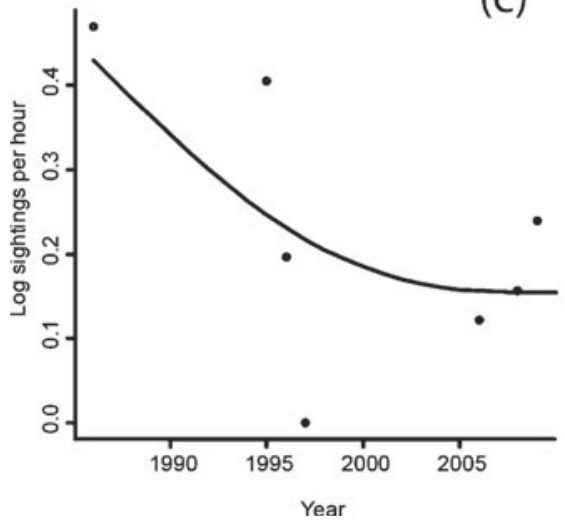

(b)

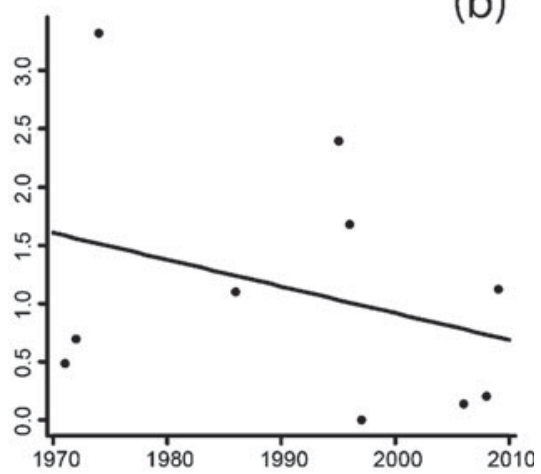

(d)

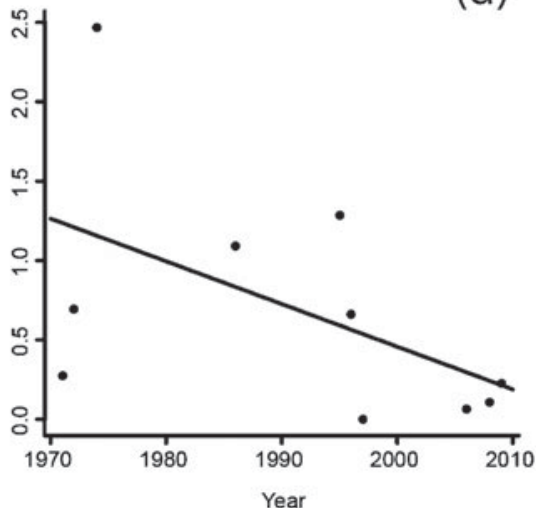

FIG. 2 Quantitative decline of frogs in the Bale Mountains (Fig. 1), shown as generalized additive modelling trends (lines) fitted to abundance (as sightings per person hour of searching; Table 1) data for focal species of frogs:

(a) Spinophrynoides osgoodi 1971-2009,

(b) Altiphrynoides malcolmi 1971-2009,

(c) Balebrevicpes hillmani 1986-2009, and (d) these three species plus

Ericabatrachus baleensis 1971-2009. piles of rotting epiphytic moss that had probably been stripped from trees during firewood collection. In contrast 18 B. hillmani were encountered (2008-2009) at a much higher rate in much less disturbed Erica forest a short distance east of the type locality. Here specimens were found under logs and in live moss, much as described for the type series (Largen \& Drewes, 1989). Seven additional specimens were found under dead wood on the lower edge of Rira, in open grassy habitat close to the road. The latter specimens extend the lower altitudinal range of the species to $2,815 \mathrm{~m}$, and are the first record of the species outside Erica forest. People in Rira reported that B. hillmani are also found among dead Hagenia/Schefflera wood used to build fences to restrict livestock close to Rira. The best-fit GAM for the pooled Tulla Negesso + Rira data suggests a significant attenuating decline ( $t=4.41, \mathrm{P}<0.01$; Fig. $2 \mathrm{c})$.

Grouping encounter data for all four endemic genera across all sites and times demonstrates a significant decline, with a best-fit linear model ( $t=3.14, \mathrm{P}>0.05$; Fig. $2 \mathrm{~d})$. All expeditions found several other species of frogs, on both the northern and southern slopes below the Sanetti Plateau (Appendix 2). These were Ptychadena (c. four species), Leptopelis (three or four species), Bufo sp., Xenopus sp., Phrynobatrachus sp., Hyperolius sp., Afrixalus sp. and Paracassina kounhiensis. In particular Leptopelis and Ptychadena were common and frequently abundant near water bodies, even at very disturbed sites in and close to
Rira. Large tadpoles, probably of L. gramineus, were found at up to c. $4,000 \mathrm{~m}$ on the edge of the Sanetti Plateau. Seventy-two frogs of 11 species were swabbed in 2008 and 2009 , and $42 \%$ (including the three focal species encountered) tested positive for the chytrid fungus Batrachochytrium dendrobatidis (Gower et al., 2012).

\section{Discussion}

B. hillmani and E. baleensis have declined substantially at their joint type locality (Tulla Negesso) in association with substantial human-induced habitat degradation. The presence of $B$. hillmani in greater numbers (and three E. baleensis) in more pristine habitat, similar to that found at Tulla Negesso 25 years ago, supports the interpretation that habitat degradation is probably the major cause of population declines at Tulla Negesso. The occurrence of $B$. hillmani under dead wood in Rira indicates that the species can survive in suitable microhabitats in disturbed areas. E. baleensis has been found only in close association with undisturbed streams and probably has a narrower range of potentially suitable habitat than B. hillmani in the changing Harenna landscape. Local people reported to the 2006-2009 field teams an increased irregularity in seasonal climate patterns but it is difficult to assess the possible impact of this upon frog populations given that our data are 

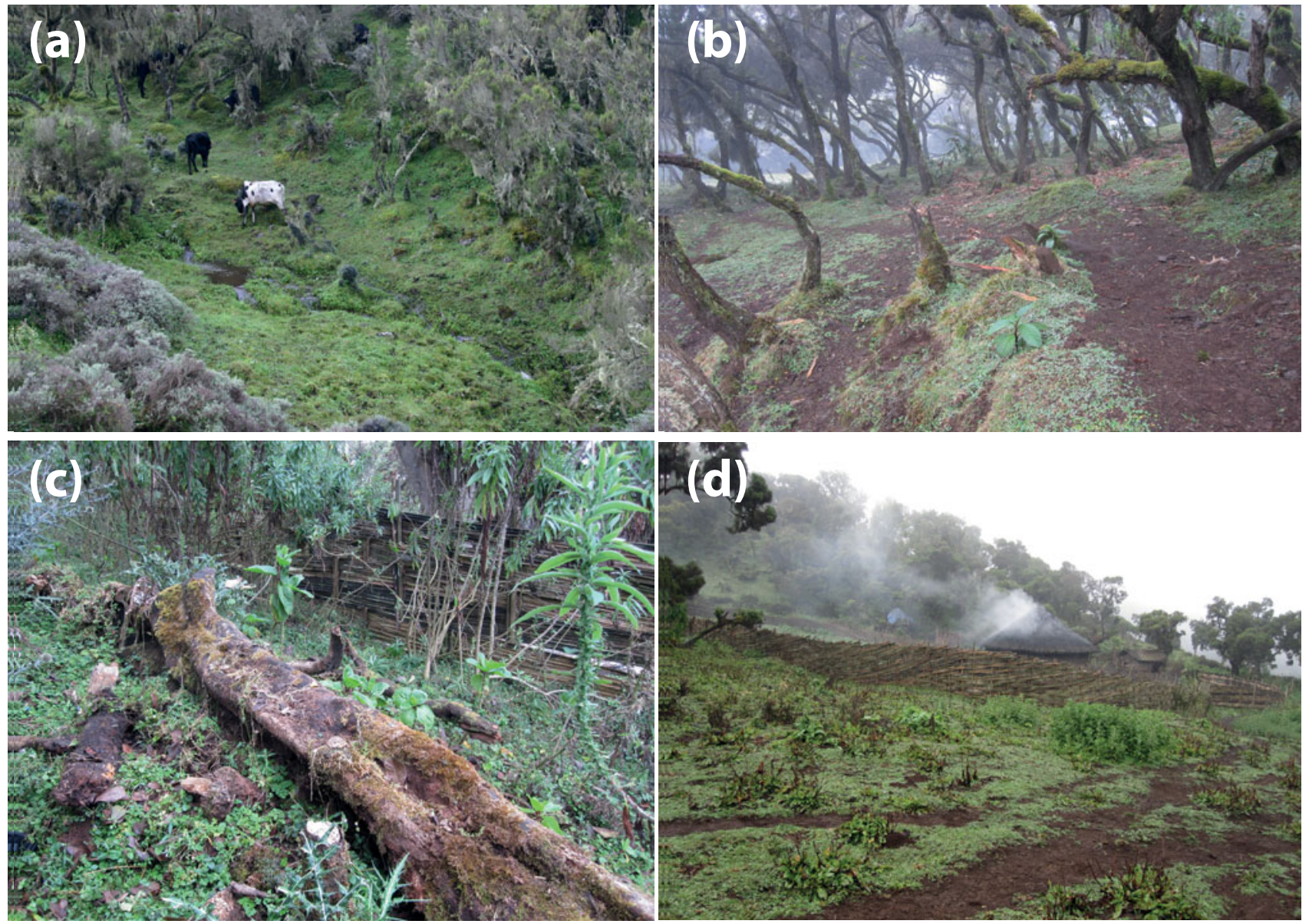

Plate 2 Habitat degradation in the Harenna Forest, Bale Mountains (Fig. 1): (a) stream trampled by cattle in Erica forest at the type locality (Tulla Negesso) of Balebreviceps and Ericabatrachus, September 2006, (b) livestock trails, cut wood and lack of ground cover in Erica forest between Tulla Negesso and Fute, December 2010, (c) collection site of Balebreviceps under rotten wood forming part of old livestock fence (new bamboo fence in background) in heavily grazed clearance just below Rira, December 2010, and (d) house and bamboo fencing in man-made clearance in Erica forest, Fute, June 2009.

from sites that have undergone rapid habitat change. More work is needed if the impact of future expected climate change is to be understood.

S. osgoodi has declined greatly in the Bale Mountains to the extent that although previously considered to be 'particularly common in the Bale Mountains National Park' (Largen \& Spawls, 2010; see also IUCN, 2010), its continued existence is not yet established. The abundance of A. malcolmi has also decreased significantly. Given our evidence, the IUCN Red List categories of these four species should be reassessed. The current IUCN assessments include statements about abundance and threat that are now known to be incorrect. Although $B$. dendrobatidis was recorded no dead or moribund frogs were found, and it remains to be seen to what extent this pathogen is implicated in the declines. Although $B$. dendrobatidis is known to kill frogs elsewhere it has been associated with the decline of only a single species of African frog, Nectophrynoides asperginus in Tanzania, and even then habitat deterioration was also implicated (Weldon \& du Preez, 2004; Channing et al., 2006).
The Bale Mountains National Park is facing major challenges (Frankfurt Zoological Society, 2007), caused chiefly by the rapidly growing human population. Even within the short period of 2006-2009 the negative impact of humans on the ecosystems of the Park was apparent, with deforestation at Harenna and increasing effects of livestock. Given that most conservation in the Bale Mountains has hitherto focused on large mammals (as elsewhere in Ethiopia, Loader et al., 2009), the threats to Bale ecosystems more generally have been under appreciated. The continued presence of endemic mammals and patches of, for example, giant Erica, could lead to the superficial conclusion that Bale forests are relatively stable but our examination of a smaller faunal element, the frogs, presents a different perspective.

We suggest several priority research objectives for the Bale amphibian fauna. More intensive and temporally and spatially broader searches for $S$. osgoodi are required, with hunts for breeding aggregations such as those described by Grandison (1978) perhaps the best target. More surveys are required to complete an inventory of the amphibians, with surveys away from roads and in more pristine habitat as well 
as in degraded ecosystems; these surveys should include areas surrounding the National Park. More basic ecological data on frogs need to be gathered, especially on the reproductive biology of $B$. hillmani and E. baleensis. More surveys are required across a range of localities and habitats to determine where monitoring efforts could best be focused. Research on other Bale organisms is required, with the works of Miehe \& Miehe $(1993,1994)$, studies of endemic mammals (see Introduction) and the Bale Mountains National Park General Management Plan (Frankfurt Zoological Society, 2007) providing a framework with which this can be integrated.

In terms of conservation management the growing numbers and destructive activities of people living within the National Park need to be addressed. When the Park is formally gazetted all settlement will be illegal but until then their status remains a grey area. Protection of key habitats is an immediate priority until human disturbance is halted across the Park. Human population growth in Ethiopia is high (Largen \& Spawls, 2010; UN, Department of Economic and Social Affairs, Population Division, 2011), and this is reflected in the increase in people living within the Park from 2,500 in 1986 (Hillman, 1986) to $>40,000$ in 2003 (Frankfurt Zoological Society, 2007). The Erica forests of the Bale Mountains have been limited historically by fire and grazing (Miehe \& Miehe, 1993, 1994) but more active deforestation is now taking place, extended grazing and wood collecting are altering the forest floor, and regeneration of these forests remains poorly understood. The importance of working properly with local people in conservation management in Africa has been recognized (Abrams et al., 2009) but we believe that within the Bale Mountains National Park the right balance has not yet been reached. The General Management Plan (Frankfurt Zoological Society, 2007) already recognizes much of what we conclude here but our data for endemic frogs emphasizes the urgency of conducting further biological research and developing appropriate conservation management in the region.

\section{Acknowledgements}

For advice, help with fieldwork, and permits for research and export, we thank (in no particular order) Hailu Tadesse, Kifle Argaw, Yeneneh Teka, Daniel Pawlos and Birutesfa Yimer (Ethiopian Wildlife Conservation Authority), Afework Bekele and Abebe Getahun (Addis Ababa University), Isa (WWF), Daniel Tilaye (Bale Mountains National Park), Ryan Kerney (Harvard University), Alastair Nelson, Anouska Kinahan and Thadaigh Baggallay (Frankfurt Zoological Society), Michael Geiser (University of Basel), Zelealem Tefera, Addis Berhanu, Sisay Shewamene, Red Jackal Tour Operators, the people of
Rira, Colin Tilbury, Bill Branch, Chris Smith, Jon Gower, Alexia Kerney, Jonathan and Tim Spawls, and our guides in 2008-2009 (Issa, Ahmed, Hussein, Hussein and Mohammed). The Harvard University expedition received funding from the Museum of Comparative Zoology's Putnam Expedition Grants. Fieldwork in 2008 and 2009 was supported in part by a National Geographic Expedition Grant (CRE Grant \#8532-08). The following bodies also funded surveys and laboratory work: Ethiopian Wildlife Conservation Authority, University of Basel, European Union Synthesys project (AAM), The Natural History Museum London (DJG, SPL), University of Richmond Faculty Research Committee (RdS), and Stipendienkommission für Nachwuchskräfte aus Entwicklungsländern, Basel (AAM).

\section{References}

Abrams, R.W., Anwana, E.D., Ormsby, A., Dovie, D.B.K., Ajagbe, A. \& Abrams, A. (2009) Integrating top-down with bottom-up conservation policy in Africa. Conservation Biology, 23, 799-804.

Adeba, P.J., Kouassi, P. \& Rödel, M.-O. (2010) Anuran amphibians in a rapidly changing environment-revisiting Lamto, Cote d'Ivoire, 40 years after the first herpetofaunal investigations. African Journal of Herpetology, 59, 1-16.

Alliance for Zero Extinction (2010) 2010 AZE Update. Http:// www.zeroextinction.org [accessed 1 July 2012].

Atickem, A., Bekele, A. \& Williams, S.D. (2009) Competition between domestic dogs and Ethiopian wolf (Canis simensis) in the Bale Mountains National Park, Ethiopia. African Journal of Ecology, $48,401-407$

Channing, A., Finlow-Bates, K.S., Haarklau, S.E. \& Hawkes, P.G. (2006) The biology and recent history of the Critically Endangered Kihansi spray toad Nectophrynoides asperginis in Tanzania. Journal of East African Natural History, 95, $117-138$.

Collen, B., Purvis, A. \& Mace, G.M. (2010) When is a species really extinct? Inferring extinction from a sightings record to inform conservation assessment. Diversity and Distributions, 16, 755-764.

COOKe, P. (1980) Optimal linear estimation of bounds of random variables. Biometrika, 67, 257-258.

Crawley, M.J. (2007) The R Book. Wiley, Chichester, UK.

Dubois, A. (1987) Miscellanea taxinomica batrachologica (I). Alytes, 5 , 7-95.

Dubois, A. (2005) Amphibia Mundi. 1.1. An ergotaxonomy of recent amphibians. Alytes, 23, 1-24.

Fewster, R.M., Buckland, S.T., Siriwardena, G.M., Baillie, S.R. \& WiLson, J.D. (2000) Analysis of population trends for farmland birds using generalized additive models. Ecology, 81, 1970-1984.

Frankfurt Zoological Society (2007) Bale Mountains National Park. General Management Plan 2007-2017. Frankfurt Zoological Society Report, Frankfurt, Germany. Http://www.zgf.de/download/ 166/BMNP_GMP_2007.pdf [accessed 1 July 2012].

FrIIS, I. (1986) Zonation of forest vegetation on the south slopes of Bale Mountains, south Ethiopia. SINET: Ethiopian Journal of Science, 9, 29-44.

Frost, D.R. (2011) Amphibian Species of the World: An Online Reference. Version 5.5. Http://research.amnh.org/vz/herpetology/ amphibia/ [accessed 1 July 2012]. 
Frost, D.R., Grant, T., Faivovich, J., Bain, R.H., Haas, A., HADDAD, C.F.B. et al. (2006) The amphibian tree of life. Bulletin of the American Museum of Natural History, 297, 1-370.

Gower, D.J., Doherty-Bone, T.M., Aberra, R.K., Mengistu, A.A., Schwaller, S., Menegon, M. et al. (2012) High prevalence of the amphibian chytrid fungus (Batrachochytrium dendrobatidis) across multiple taxa and localities in the highlands of Ethiopia.

Herpetological Journal, 22, 225-233.

Grandison, A.G.C. (1978) The occurrence of Nectophrynoides (Anura Bufonidae) in Ethiopia. A new concept of the genus with a description of a new species. Monitore Zoologico Italiano (Nuova Serie) Supplemento, 11, 119-172.

Green, D.M. (2003) The ecology of extinction: population fluctuation and decline in amphibians. Biological Conservation, 111, 331-343.

Hillman, J.C. (1986) Bale Mountains National Park. Management Plan. Ethiopian Wildlife Conservation Organization, Addis Ababa, Ethiopia.

Hillman, J.C. (1988) The Bale Mountains National Park area, southeast Ethiopia, and its management. Mountain Research and Development, 8, 253-258.

IUCN (2004) IUCN Red List of Threatened Species 2004. Http://www. iucnredlist.org [accessed 15 October 2005].

IUCN (2010) IUCN Red List of Threatened Species v. 2010.3. Http:// www.iucnredlist.org [accessed 22 September 2010].

Kilpatrick, A.M., Briggs, C.J. \& Daszak, P. (2010) The ecology and impact of chytridiomycosis: an emerging disease of amphibians. Trends in Ecology \& Evolution, 25, 109-118.

Largen, M.J. (1991) A new genus and species of petropedatine frog (Amphibia Anura Ranidae) from high altitude in the mountains of Ethiopia. Tropical Zoology, 4, 139-152.

LARGEN, M.J. (2001) Catalogue of the amphibians of Ethiopia, including a key for their identification. Tropical Zoology, 14, 307-402.

Largen, M.J. \& Drewes, R.C. (1989) A new genus and species of brevicpitine frog (Amphibia Anura Microhylidae) from high altitude in the mountains of Ethiopia. Tropical Zoology, 2, 13-30.

Largen, M.J. \& Spawls, S. (2010) The Amphibians and Reptiles of Ethiopia and Eritrea. Chimaira, Frankfurt Am Main, Germany.

Loader, S.P., Gower, D.J., Howell, K.H., Doggart, N., RöDel, M.-O., Clarke, B.T. et al. (2004) Phylogenetic relationships of African microhylid frogs inferred from DNA sequences of mitochondrial $12 \mathrm{~S}$ and $16 \mathrm{~S}$ rRNA genes. Organisms, Diversity \& Evolution, 4, 227-235.

Loader, S.P., Mengistu, A., Schwaller, S., Gower, D. Nagel, P.N., Getahun, A. et al. (2009) Are Ethiopian highlands changing? Amphibians as ecosystem indicators. Mountain Forum Bulletin, 9, 5-6.

Loveridge, A. (1932) Eight new toads of the genus Buho from East and Central Africa. Occasional Papers of the Boston Society of Natural History, 8, 43-54.

Malcolm, J. \& Evangelista, P.H. (2005) The Range and Status of the Mountain Nyala. Ethiopian Wolf Conservation Programme Report. Http://www.ethiopianwolf.org/publications/Malcolm-Evangelista2005-Mountain-Nyala-Report.pdf [accessed 1 July 2012].

MARSH, D.M. (2001) Fluctuations in amphibian populations: a metaanalysis. Biological Conservation, 101, 327-335.

Meronnen, A. (2008) Distribution of the Bale monkey (Chlorocebus djamdjamensis) in the Bale Mountains and its ecology in the Odobullu Forest, Ethiopia-A study of habitat preference, population size, feeding behaviour, activity and ranging patterns. MSc thesis. Addis Ababa University, Addis Ababa, Ethiopia. Http://www.
ethiopianwolf.org/publications/Addisu\%2oBale\%2omonkey\% 20Thesis\%20July\%202008.pdf [accessed 28 June 2012].

Mekonnen, A., Bekele, A., Hemson, G., Teshome, E. \& Atickem, A. (2010) Population size and habitat preference of the Vulnerable Bale monkey Chlorocebus djamdjamensis in Odobullu Forest and its distribution across the Bale Mountains, Ethiopia. Oryx, 44, 558-563.

Meyer, A.H., Schmidt, B.R. \& Grossenbacher, K. (1998) Analysis of three amphibian populations with quarter-century long timeseries. Proceedings of the Royal Society, B, 265, 523-528.

Miene, G. \& Miehe, S. (1993) On the physiognomic and floristic differentiation of ericaceous vegetation in the Bale Mountains, SE Ethiopia. Opera Botanica, 121, 85-117.

Miene, S. \& Miene, G. (1994) Ericaceous Forests and Heathlands in the Bale Mountains of South Ethiopia. Stiftung walderhaltung in Afrika \& Bundesforschungsansalt für Forst- und Holzwirtschaft, Hamburg, Germany.

Müller, H., Loader, S.P., Ngalason, W., Howell, K.M. \& Gower, D.J. (2007) Reproduction in brevicipitid frogs (Amphibia: Anura: Brevicipitidae)-evidence from Probreviceps $m$. macrodactylus. Copeia, 2007, 726-733.

Pechmann, J.H.K., Scott, D.E., Semlitsch, R.D., Caldwell, J.P., Vitt, L.J. \& Gibions, J.W. (1991) Declining amphibian populations: the problems of separating human impacts from natural fluctuations. Science, 253, 892-895.

Pıмm, S.L. (2007) Africa: still the dark continent. Conservation Biology, $21,567-569$.

R Development Core Team (2010) R: A language and Environment for Statistical Computing. R Foundation for Statistical Computing, Vienna, Austria.

Semlitsch, R.D., Scott, D.E., Pechmann, J.H.K. \& Gibbons, J.W. (1996) Structure and dynamics of an amphibian community. Evidence from a 16-year study of a natural pond. In Long-Term Studies of Vertebrate Communities (eds M.L. Cody \& J.A. Smallwood), pp. 217-248. Academic Press, San Diego, USA.

Sillero-Zubiri, C., Macdonald, D. \& IUCN/Species Survival Commission Canid Specialist Group (1997) The Ethiopian Wolf-Status Survey and Conservation Action Plan. IUCN, Gland, Switzerland.

Solow, A.R. (2005) Inferring extinction from a sighting record. Mathematical Biosciences, 195, 47-55.

Stuart, S.N., Hoffman, M., Chanson, J.S., Cox, N.A., Berridge, R.J., Ramani, P. \& Young, B.E. (2008) Threatened Amphibians of the World. Lynx Edicions, Barcelona, Spain, IUCN, Gland, Switzerland \& Conservation International, Arlington, USA.

Tandy, M. \& Keith, R. (1972) Bufo of Africa. In Evolution in the Genus Bufo (ed. W.F. Blair), pp. 119-170. University of Texas Press, Austin, USA.

UN, Department of Economic and Social Affairs, Population Division (2011) World Population Prospects: The 2010 Revision. Http://esa.un.org/unpd/wpp/Documentation/ publications.htm [accessed 1 July 2012].

Weldon, C. \& DU PreEZ, L.H. (2004) Decline of Kihansi spray toad, Nectophrynoides asperginis, from the Udzungwa mountains, Tanzania. Froglog, 62, 2-3.

Wood, S.N. (2006) Generalized Additive Models: An Introduction. Chapman and Hall/CRC Press, Boca Raton, Florida, USA.

WCMC (World Conservation Monitoring Centre) (1993) World Checklist of Threatened Amphibians. Joint Nature Conservation Committee, Peterborough, UK. 


\section{Appendices 1-3}

The appendices for this article are available online at http:// journals.cambridge.org

\section{Biographical sketches}

DAVID GOWER is a herpetologist specializing in systematics and evolution. ROMAN ABERRA works in Ethiopian conservation, with a special interest in frogs. Silvia Schwaller conducted her Masters thesis on environmental change in the Harenna Forest. MaLcolm Largen is a leading authority on herpetology in Ethiopia. Ben Collen is a conservation biologist with expertise in quantitative analysis. Steven Spawls is an expert in East African herpetology. Michele Menegon researches the diversity and evolution of East African amphibians and reptiles. BREDA ZimKus is a herpetologist with expertise in African frogs. Rafael de $\mathrm{S}_{\mathrm{A}}$ is an amphibian biologist with expertise in tadpole biology. Abebe Mengistu has expertise with Ethiopian fish and frogs. Fikirte Gebresenbet is a conservation biologist working in her native Ethiopia. ROBIN MOORE is an amphibian conservation biologist. SAMY SABER is an expert on the ecology of African amphibians and reptiles. Simon LoAder studies African (especially Afromontane) amphibian systematics and evolution. 